\title{
RAMÓN DE NAVARRETE Y MISTERIOS DEL CORAZÓN (1845): CIUDAD DEL LUJO Y DEL GLAMOUR ${ }^{1}$
}

\author{
Borja RODRÍGUEZ GUTIÉRREZ
}

Universidad de Cantabria

\section{RESUMEN}

El artículo da una noticia de la vida y obra de Ramón de Navarrete, mecionando su necrológica de Larra y su labor como autor teatral. Explica con más detalle su labor de periodista especializado en la crónica de la alta sociedad, pues resulta importante para comprender mejor la novela. A continuación analiza la novela Misterios del Corazón (1845) de la que destaca tres elementos. El primero, que se trata de una novela de costumbres urbanas que refleja con fidelidad y realismo espacios urbanos que existían en el Madrid de la época. El segundo, la construcción teatral de la novela. Y el tercero las ilustraciones que acompañan al texto, y su relación con los elementos anteriores. Palabras Clave: Ramón de Navarrete, Misterios del Corazón, literatura ilustrada, novela, realismo.

\section{ABSTRACT}

The article gives a news of the life and Ramon de Navarrete's work, mentioning his Larra's necrological one and his labor as theatrical author. It explains with more detail his labor of journalist specialized in the chronicle of the high company, since it turns out important to understand better the novel. Later the novel analyzes Misterios del Corazón (1845) of that emphasizes three elements. The first one, which treats himself about an urban novel of customs that reflects with loyalty and realism urban spaces that existed in Madrid of the epoch. The second one, the theatrical construction of the

1. Este trabajo forma parte del proyecto de investigación Análisis de la Literatura Ilustrada del siglo XIX, dependiente del Plan Nacional de I+D+I 2008-2011 del Gobierno de España, Ref. n FFI2008/0035FILO. 
novel. And the third party the illustrations that they accompany on the text, and his relation with the previous elements.

Key words: Ramón de Navarrete, Misterios del Corazón, Illustrated literature, Novel, Realism.

\section{EL ESCRITOR}

Un reciente artículo de Rubio Cremades (2008) constituye el único acercamiento crítico que ha habido a la figura de Ramón de Navarrete en los últimos cincuenta años. Una situación curiosa para un escritor que estuvo en la primera fila de la vida literaria del tiempo que le tocó vivir, que fue la mayor parte del siglo XIX. Novelista, dramaturgo y periodista, su larga vida le permitió ser discípulo de Alberto Lista en su juventud, y muchos años después, introductor en los salones madrileños de un joven llamado Marcelino Menéndez Pelayo ${ }^{2}$. Se convirtió en una presencia constante en el Madrid literario, prácticamente en una institución, hasta tal punto que Pérez Galdós dijo de él que era «más viejo que la Cuesta de la Vega» ${ }^{3}$. Pero, fallecido a las puertas del nuevo siglo (1897), su memoria fue borrándose poco a poco, hasta convertirse en un nombre más, de los muchos que pululan por el Espasa y su obra no ha merecido estudios. Y sin embargo hay en Navarrete un escritor con voz propia, y con obras de interés que conviene rescatar.

Sobre la fecha de nacimiento de Navarrete hay dudas. En el artículo citado de Rubio Cremades se indica 1818, mientras que Ovilo y Otero (1860) apunta 1820. Tanto Ovilo y Otero como Martínez de Velasco (1891) lo sitúan como discípulo de Alberto Lista y amigo y protegido de Espronceda. Ovilo y Otero, en concreto, afirma que fue Espronceda quien intercedió ante Julián Romea, para que éste pusiera en escena la primera obra original de Navarrete, Emilia.

Redactor de la Gaceta desde muy joven, gracias al apoyo de Espronceda, publicó en ese periódico numerosas críticas teatrales. Una nota necrológica

2. Así recuerda Enrique Menéndez Pelayo una calaverada de su juventud en Madrid, allá por 1881. «A punto estuvimos de que se nos aguara la fiesta, pues bajando durante un intermedio de la función al foyer guipamos desde la escalera a mi hermano Marcelino, de quien todo el día andábamos huyendo, y que se dirigía hacia la sala. Acompañábale otro señor de mucha más edad que él, aunque muy restaurado y compuesto. Corriendo los tiempos tuve ocasión de conocerle: era el famoso cronista de salones Asmodeo, estimable novelista y, además, dramaturgo» (1983: 187)

3. «¿No ves en otro grupo a Ramón de Navarrete? ¡Oh, le grand critique de société, por mal nombre Asmodeo! Dicen que es más viejo que la Cuesta de la Vega, pero está muy espigadito todavía.». Rubio Cremades hace notar que Navarrete aparece también en Juanita la Larga de Valera y en Pequeñeces del Padre Coloma, en ambos caso en su faceta de conocedor de la aristocracia y de los salones. 
sobre Larra, publicada el 4 de marzo de $1837^{4}$, significó, según Ovilo y Otero, el lanzamiento de su carrera literaria: «El juicio que publicó a la muerte de Larra, fue el que más contribuyó a su popularidad y lo colocó a la altura en que se encuentra todavía» (1860: 50$)^{5}$.

Es una necrológica, la de Navarrete, que da muestra de la incomodidad que había provocado en buena parte de la sociedad de su época la ácida crítica de Fígaro. El texto, bajo el lamento por la muerte del «escritor cuyas obras excitaban la risa y eran para todos objeto de predilección» se convierte en una defensa de la sociedad a la que Larra criticaba:

Ideas exageradas o una fantasía acalorada llevaron a Larra al sepulcro, que abrió con sus propias manos sin acordarse de que su vida ya no era suya, que debía consagrarla a su patria y a sus hijas, que su ejemplo seria tal vez pernicioso a esa sociedad no tan estúpida ni tan corrompida como se pretende, y en la cual aún brillan virtudes y sentimientos nobles a la par de acciones desinteresadas. ¡Y así era como pretendía corregir los vicios?... ¿así como quiso demostrar la exactitud de sus doctrinas?... Por fortuna esa sociedad, que se calumnia, que se llama estúpida y corrompida, no está tan desprovista de ilustración y de virtud que no se aparte de un ejemplo vivo de demencia, ni deje de reprobar altamente un acto que si mueve a compasión, causa también horror y estremece a la naturaleza. (Las cursivas son de Navarrete).

Las ideas del Navarrete de diecisiete o diecinueve años que redactó esta necrológica se iban a mantener, en lo fundamental, a lo largo de toda su carrera: defensa, es más, exaltación de la sociedad y de la vida social, desconfianza de los extremos, conservadurismo. Desde el principio de su obra se nos muestra como un personaje acomodado confortablemente en la sociedad de su tiempo. Esa tranquila aceptación de la realidad social, política y cultural de su época fue la clave principal de un éxito y de una estima de la que disfrutó sin interrupción a lo largo de sesenta años.

A partir de esa necrológica inicia una gran actividad literaria, como dramaturgo, como novelista y como periodista. Esta última actividad fue la que le reportó más fama. Creó un nuevo género: la crónica social. Artículos en los que se describían con minuciosidad, con deleite y sin un ápice de crítica, los bailes, las fiestas y las actividades de la gran sociedad madrileña, que conocieron un enorme éxito. Iniciadas en las Crónicas madrileñas, firmadas con el seudónimo Pedro Fernández, continuaron con una serie de artículos en La Época, con la firma de Asmodeo y ya más avanzado el siglo con los artículos de La Moda Elegante que firmaba como El Marqués de Valle-Alegre. Esta actividad

4. Apareció publicada sin firma.

5. Vease Anexo 1.

Anales, 24, 2012, pp. 43-66 
fue la que le hizo más célebre y la que retratan en sus novelas, Coloma, Valera y Pérez Galdós. Fue imitado por muchos pero a lo largo de su vida mantuvo la primacía en ese campo. De hecho, sus crónicas fueron un elemento muy importante del triunfo de La Época, y llegaron a convertirse en una de las señas de identidad de ese periódico. Así nos lo indica Pedro Antonio de Alarcón, en Diciembre de 1859, en este comentario de Diario de un testigo de la guerra de África:

También hemos recibido el correo de España, de dos días, durante los cuales no ha sido posible pasar el Estrecho... ¡Ah, Pedro Fernández! ¡Conque tan buen invierno se prepara en Madrid! ¡Conque ya se abren los salones, y se empieza a bailar, y contáis con la Ristori, y habrá concierto en casa de la condesa del Montijo! Ya ves que también aquí se leen tus Cartas Madrileñas... ¡Y si supieras qué penosa impresión nos causan! ¡No sé cómo el general Ros de Olano, tan cuidadoso de la alegría de sus tropas, no ha prohibido a La Época la entrada en el Campamento! ¡Bailes! ¡Teatros! ¡Música! ¡Amable conversación! ¡Amores! ¡Casamientos! ¡Fuente castellana...! ¿A qué nos recuerdas todas esas cosas? ¡Oh, qué cruel te ha tornado tu familiaridad con el bello sexo! (Alarcón: 1856: 36)

Sin duda ha sido esa faceta de luminaria social, amigo de Condesas, Marquesas y Duquesas, amable cronista de la aristocracia y gran entendido en modas, decoraciones y adornos, lo que más se recuerda de él. Pero Navarrete fue también novelista y dramaturgo de éxito y reconocimiento.

Su éxito teatral más importante fue Don Rodrigo Calderón o la caída de un ministro, estrenada en 1841 y que obtuvo gran éxito. Agustín Challamel, historiador francés, que en 1843 publicó Un eté en Espagne ${ }^{6}$, lleva cartas de presentación para dos célebres escritores españoles del momento: Mesonero Romanos y Ramón de Navarrete, «auteur de Don Calderón (sic.), drame d'un grand mérite» (Challamel, 1843: 188) ${ }^{7}$. Rubio Cremades (2008: 287-87, n. 2) da noticia de casi cien títulos entre obras originales, traducciones y adaptaciones. Uno de los autores más representados de su época. Prueba de su presencia en las tablas es que fuera uno de los fundadores de la Sociedad de Autores Dramáticos, entidad que bajo la protección de José de Salamanca y con Antonio Gil y Zárate como director, pretendió constituirse en editorial

6. El verano de 1842 .

7. El recibimiento de Mesonero y de Navarrete al viajero francés fue muy acorde con las respectivas personalidades de cada uno. Mesonero le recibió con mucha cortesía, conversó con él y le pidió, al saber que estaba escribiendo un relato de su viaje que tratara con justicia las cosas de España: «me pria d'être juste, si j'écrivais sur son pays»(188). Navarrete le recibió, le facilitó la entrada al Ateneo, lugar que Challamel alaba sin reservas, le hizo entrar en La Moncloa y le sirvió de guía por los salones de la buena sociedad madrileña. Challamel indica sobre Navarrete que «je puis appeler mon mi» (188) 
para conseguir más beneficios para los autores y al mismo tiempo establecer relaciones sólidas con los teatros de las provincias. En la circular, de 31 de diciembre de 1848 , que anunciaba la sociedad ${ }^{8}$ se indica que «figuran casi todos los que hasta ahora se han granjeado alguna reputación en esa clase de literatura». La lista de autores estaba integrada por Manuel Bretón de Los Herreros, Leopoldo Augusto de Cueto, José María Díaz, Patricio de la Escosura, Carlos García Doncel, Antonio García Gutiérrez, Antonio Gil y Zárate, Isidoro Gil, Juan Eugenio Hartzenbusch, El Duque de Rivas, Tomás Rodríguez Rubí, Luis Olona, Luis Valladares y Garriga y Ramón de Navarrete. En suma la plana mayor del teatro romántico (con la excepción de Ventura de la Vega y José Zorrilla) entre los que se encontraba nuestro autor.

Rubio Cremades en su artículo se detiene más en su faceta de novelista, que se inició en 1843 con Creencias y Desengaños. Este título fue el primero de una nueva colección de novelas: Crónicas españolas, colección de novelas originales. Dirigida por Ignacio José Escobar, esta colección, en el anuncio de su constitución ${ }^{9}$, hizo constar los títulos que pensaba publicar: Higiene social, de Ramón de Campoamor; El mundo nuevo, de Ignacio José Escobar; Los amantes de Teruel de Juan Eugenio Hartzenbusch; La enferma del corazón, de Gregorio Romero Larrañaga; Laura de Sandoval de Diego Coello y Quesada; Una leyenda de José Zorrilla; La Madrastra, de Juan Martínez Villergas y Don Rodrigo Calderón, de Carlos García Doncel. La colección debió ser un fracaso, pues de todos estos títulos solo el de Romero Larrañaga llegó a publicarse (al menos no he localizado referencias del resto), pero de nuevo encontramos a Navarrete codeándose con autores en esos momentos ya consagrados como Zorrilla, Hartzenbusch, Campoamor o Romero Larrañaga.

\section{LA NOVELA}

Misterios del Corazón apareció en cinco números de El Siglo Pintoresco en $1845^{10}$, en 1849 volvió a ser publicado, en el folletín de La Época, entre abril y mayo ${ }^{11}$, y ese mismo año apareció en libro, impreso en Sevilla, por Gómez ${ }^{12}$. Todo ello indica que Navarrete estaba satisfecho de su obra.

8. El Heraldo. $\mathrm{N}^{\circ} 479.31$ de diciembre de 1848. Página 2.

9. El Heraldo, 11 de mayo de 1843, página 4.

10. Entrega 2: abril de 1845; Entrega 4: mayo de 1845; Entrega 6: junio de 1845; Entrega 9: Julio de 1845; Entrega 12: agosto de 1845.

11. Desde el 24 de abril hasta el 3 de mayo en 8 números de La Época: del 19 al 27.

12. Misterios del corazón, novela original, por Don Ramón de Navarrete. Sevilla. Imprenta de Gómez editor, calle de la Muela, 32. 1849, 110 pp. 
La historia que narra Misterios del Corazón es sencilla: El marqués de Vivarrambla, casado desde hace seis años, es amante de Adela de Arambarri, amiga de su esposa, Clementina, la marquesa de Vivarrambla. Absolutamente indiferente a los sentimientos de su mujer se complace en aparecer en público acompañado de su amante y su esposa. En una sociedad que todo se comenta y se sabe, las relaciones del marqués y de Adela son públicas y notorias y la marquesa de Vivarrambla es objeto de burla generalizada. Viendo la situación, el Conde de Peñaflor, un dandy desocupado y egoísta, se hace amigo del Marqués con la idea de aprovechar el despecho de Clementina para seducirla y triunfar públicamente con tal difícil conquista. Clementina se resiste a los intentos del Conde, e implora el auxilio de su marido que le hace un desprecio público en el teatro ante toda la sociedad. El Conde acompaña a una furiosa Clementina a su hogar mientras el marqués se queda tranquilamente en el teatro con su amante. Peñaflor aprovecha el momento para entregar a Clementina una carta que ha robado al Marqués, en la que hay pruebas de sus relaciones amorosas con Adela, relaciones en que hasta el momento Clementina se ha negado a creer. Peñaflor se oculta ante la llegada del Marqués, que entra en la habitación de Clementina con idea de reconvenirla por dar escenas en público, pero ésta le enseña la carta y le exige la separación. El Marqués, conmocionado accede a la separación, a que la Marquesa se quede con sus dos hijos y a que siga viviendo en esa casa de donde él se irá. En el momento que Clementina deja de ser una ridícula esposa engañada y pasa a ser una mujer digna y altiva, el Marqués siente que se ha enamorado, por primera vez, de una mujer con la que estaba casado pero a la que nunca quiso. Intenta en ese momento la reconciliación, pero Clementina le conmina a irse de la casa y no volver a verla. La escena ha sido observada en todo momento por Peñaflor, que estaba oculto en la alcoba contigua al salón. Cuando el Marqués se va, Clementina propone a Peñaflor un trato: ella aparecerá en público como su amante, pero en privado no tendrán ninguna relación, salvo que Clementina decida otra cosa. El Conde acepta sin dudar y abandona también la casa en la que Clementina, una vez sola, cae desmayada. La novela continúa con un intervalo de unos meses. Clementina, a quien todos creen amante de Peñaflor, con el que reiteradamente se exhibe en público, se ha convertido en una estrella de los salones aristocráticos. Asiste a todas las fiestas, es admirada por su belleza y por su elegancia, y es la indiscutible reina de la temporada. El Marqués ha enfriado mucho sus relaciones con Adela a la que trata con indisimulado desprecio; tanto que Adela decide el matrimonio con Justo Paniagua, provinciano torpe y ridículo, primo de Peñaflor y personaje cómico del relato. Para reconquistar a su mujer, el marqués ha cuidado su indumentaria, antes 
muy desarreglada y se ha acicalado su pelo y barba. Ha cambiado sus hábitos de vida y ahora frecuenta la sociedad elegante, cosa que antes no hacía, para tener oportunidad de hacerse ver a los ojos de su mujer. En una fiesta en una casa aristocrática en la que la Marquesa obtiene un gran éxito como cantante, el Marqués se acerca a su mujer y entablan conversación. Peñaflor, que lo observa, se acerca y hace unas observaciones irónicas. El Marqués se ríe de la situación en la que un amante está celoso de un marido, el Conde se ofende y la conversación termina en un desafío. Clementina conmocionada se vuelve a su casa y el Marqués la acompaña. Una y otro se explican mutuamente sus sentimientos y se dan cuenta de que siguen enamorados. En ese momento llega el Conde y Clementina pide a su marido que se esconda y oiga la conversación. El Conde furioso le dice a Clementina que a la mañana siguiente se bate y que ya que puede morir, desea morir por algo y no por nada. En la conversación subsiguiente se comprueba que nunca han sido amantes y Clementina trata al Conde con desprecio y dureza y le acusa de pretender usarla como un mero trofeo ante la sociedad. Finalmente el Conde se marcha de la casa frustrado y jurando vengarse y el Marqués comprueba que pese a las apariencias, su mujer le ha sido fiel.

Un personaje secundario nos cuenta el final de la historia. En el desafío el Marqués le ha destrozado un brazo al Conde, brazo que habrá que amputarle. El matrimonio, con sus hijos, ha abandonado Madrid y se ha instalado en París sin intención alguna de volver como lo prueba el hecho de que han vendida la casa; precisamente a Justo Paniagua que se va a casar con Adela. Ante el escándalo y el asombro de sus contertulios, este personaje que nos da las últimas noticias comenta: «Son misterios del corazón».

\section{NOVELA URBANA Y DE COSTUMBRES}

Es indudable que a la hora de analizar esta breve novela no puede dejarse de tener en cuenta la fecha: 1845. En el artículo citado con anterioridad, Rubio Cremades indicaba que «es evidente de la existencia de una novela de costumbres en la década de los años treinta y cuarenta» (2008: 240). Russell P. Sebold indica que «el primer decenio del realismo moderno, no es el de 1870, sino el de 1840» (2007:15). Ambos críticos citan a este respecto novelas como Los cortesanos y la revolución de Eugenio de Tapia (1838-1839), La protección de un sastre de Miguel de los Santos Álvarez $(1840)^{13}$, El poeta y el banquero. Escenas

13. Habría que citar aquí además, como otras muestras del realismo, los dos relatos que Miguel de los Santos Álvarez publica en 1841 con el título «Agonías de la Corte». Publicados primero en El Iris, la «Agonía segunda» quedó incompleta. Su autor, ese 
contemporáneas de la revolución española de Pedro Mata (1842), Madrid y sus misterios de Jacinto de Salas y Quiroga (1844) o María o la hija de un jornalero de Wenceslao Ayguals e Izco (1845). Es pues, Misterios del Corazón, una más de esas obras que demuestran la existencia de una narrativa interesada por la realidad en la década de 1840. Pero, además, la novela ofrece el interés de ofrecer una realidad distinta, de encontrar nuevos espacios y nuevos personajes para la narrativa. Espacios y personajes netamente urbanos, de gran ciudad además, de clase alta, de lujo y de glamour. Un espacio urbano que Navarrete conocía a la perfección y en el que se desenvolvía con plena comodidad.

La historia que se cuenta es indisociable del escenario urbano, adinerado y aristocrático en el que se desarrollan los acontecimientos. Lo que significa a Misterios del Corazón, entre todas sus hermanas de década, es encontrar ese nuevo espacio urbano. Otras novelas están más centradas en una clase media que tiene que hacer frente a estrecheces y problemas de la vida diaria, que se tiene que enfrentar a cambios y a sobrevivir en ambientes que ofrecen múltiples dificultades. Los personajes de Misterios del Corazón carecen de todo tipo de problemática económica y, por lo que sabemos de ellos, de cualquier actividad laboral. Su vida se reparte entre las fiestas, los cafés, los teatros y las inagotables tertulias y conversaciones, centrados todos en la vida, amorosa y sexual, de los demás. Es una sociedad en la que se vive en público y ante el público, entregada a la murmuración y al constante escrutinio del prójimo, donde todos los actos y movimientos son observados analizados y comentados.

En este sentido, podemos considerar a Misterios del Corazón como una novela urbana, una de las primeras novelas urbanas españolas, y probablemente la primera que plantea como escenario novelesco la ciudad de la alta burguesía y la aristocracia, del dinero y de las fiestas, de la sociedad brillante y aparente, de las gentes que acuden a los sitios de moda a ver y a ser vistos. Las palabras que antes citábamos del Alarcón periodista en África («iBailes! ¡Teatros! ¡Música! ¡Amable conversación! ¡Amores! ¡Casamientos!») son una buena descripción del ambiente de Misterios del Corazón, donde no faltan

mismo año de 1841, vuelve a publicar ambos cuentos, ahora en su totalidad, en El Pensamiento, la revista del grupo de Espronceda. Los dos relatos que coinciden con $\mathrm{La}$ protección de un sastre en presentar el ambiente real del Madrid contemporáneo desde una perspectiva irónica. Azorín, de seguro, les habría dedicado el mismo juicio que dedica a la novela de Álvarez: «Hay mucho sarcasmo, sarcasmo fácil, encimero y copia de ironía, ironía a todos pasto, fruslera también en esta novelita» (1946: 3). Cierto es lo del sarcasmo, pero también que es un sarcasmo novedoso y original, y que con los cuentos de Santos Álvarez aparece una nueva realidad, o al menos una nueva visión de la realidad en la literatura de esos momentos (Rodríguez Gutiérrez, 2004: 342-353). 
bailes, teatros, música, amables conversaciones, amores y casamientos. El lector de la novelita de Navarrete va a emprender un viaje por los espacios naturales del lujo y del glamour ciudadano, reservados en la vida real a los poderosos; al tiempo que la historia, el lector va a conocer las costumbres y las actividades de los aristócratas y los millonarios, la vida de una ciudad que está junto a los lectores del Siglo Pintoresco, vida a la que ellos no tienen acceso.

Así por ejemplo, nos presenta Solís, ese abogado que tantas veces nos sirve en la historia de narrador, las actividades del Marqués de Vivarrambla para conquistar a su esposa; si la marquesa se ha convertido en la estrella de la temporada, el marqués se ha vuelto un perfecto caballero a la moda:

a su antiguo desaliño ha reemplazado la más refinada elegancia en su traje y en sus maneras. Dos o tres veces pasa todos los días desempedrando las calles en un magnífico caballo, que monta con extremada gallardía, por delante de los balcones de la Marquesa, que suelen permanecer implacablemente cerrados; luego suele seguir su coche en el Prado, caracoleando graciosamente detrás; en fin, por la noche se coloca en una luneta situada frente al palco de su cónyuge, a la que echa los anteojos con frecuencia y obstinación.

He aquí las actividades de la gente de clase, inseparables de la vida en la ciudad, en esa ciudad del buen tono que hasta Navarrete nunca había sido un espacio propio para la narración.

El cronista social cede al novelista el escenario y de esa manera explota la fascinación que siente el público lector ante la vida de adinerados y aristócratas. En la novela aparecen por doquier las referencias al lujo, al buen gusto y a la elegancia. El Conde de Peñaflor, «vestía con extremado lujo y a la vez con arreglo al último figurín llegado de Francia», el volante (criado) que acompaña a los Marqueses de Vivarrambla el café de Venecia iba «vestido con extremado lujo»; en el gabinete de la Marquesa, el narrador se detiene en «un magnifico reló de porcelana de Sevres». Al describir la escena de la fiesta, Navarrete indica que «los suntuosos salones del Palacio de $\mathrm{A}^{* * *}$ estaban adornados con lujo y con novedad singulares». La Marquesa en ese baile se presenta con carísimas joyas: «Llevaba la Marquesa un traje blanco de raso, y encima una segunda falda de encaje sujeta y levantada de los lados con broches de deslumbradores brillantes: en el pecho ostentaba también riquísima pedrería, y en su cabeza una corona diamantina de incalculable valor.» Incluso en la escena en la que Clementina se desvanece, agotada por la tensión, en la habitación no se priva el novelista de indicar que la alfombra en la que se cae inconsciente, era «magnífica».

Al lujo le acompaña, como complemento indispensable, la elegancia. Por ello Navarrete se detiene con especial interés en el atuendo con que aparecen los personajes principales. El narrador admira y alaba sin reservas el cuidado 
en el vestir, la elegancia y la sujeción a la moda. No es casualidad que al principio del relato, cuando el Marqués se nos presenta como un personaje extraviado, inmoral y desagradable, que trata con desprecio a su mujer, y llega ser ofensivo con ella, su forma de vestir sea inapropiada:

habría sido un modelo de belleza varonil, si hubiese cuidado más de su compostura y de su aseo. Una barba profusa le cubría la mitad de la cara, y se perdía entre los bucles de sus cabellos castaños. Llevaba una levita raída y antigua, abrochada de modo que no se le veía la camisa; un sombrero sucio y viejo, y unos pantalones a cuadros de colores claros; lo que formaba un todo de malísimo efecto a primera vista.

Pero cuando vuelve al buen camino, cuando se transforma, deja el amor de Adela y lucha por recuperar el amor de su mujer, cuando se convierte en un personaje positivo, su aspecto físico se hace muy diferente:

realzaban la figura varonil e interesante del Marqués todos los accesorios de la riqueza y del buen gusto; él antes tan descuidado en su traje, por no decir tan sucio; tan poco elegante, por no decir tan ramplón, vestía entonces con arreglo a las leyes imperiosas de la última moda; sus cabellos que antes caían sobre su levita en desiguales guedejas, estaban artísticamente divididos y rizados sobre su hermosa cabeza; su barba que crecía cual una planta inculta cubriendo la mejor parte de su rostro, se hallaba afeitada con raro esmero y perfecta simetría; en fin, en lo tocante a su adorno, el Conde de Peñaflor mismo, que pasaba en otro tiempo por el primer dandy de la corte, se veía precisado a cederle la primacía. Digámoslo de una vez; el hombre más distinguido por su belleza, por su gracia y por sus modales, entre los muchos que ocupaban el salón, era indudablemente el Marqués de Vivarrambla.

Riqueza, buen gusto, adorno, simetría, esmero; y sobre todo «arreglo a las leyes imperiosas de la última moda». La evolución moral del personaje va ligada a su transformación física: las leyes imperiosas de la última moda son admitidas sin reservas por Navarrete, como normas positivas y necesarias.

Precisamente la atención a la moda hace de Misterios del corazón una novela no sólo urbana, sino también rigurosamente contemporánea, casi podríamos decir de actualidad periodística. Podemos ver esto en el personaje de Justo Paniagua, que excita la risa del público del teatro del Circo, al aparecer en un atuendo que él considera elegante:

Venía desconocido con su nuevo traje, cien veces más extraño que el que llevaba una hora antes. Habíase puesto un chaleco blanco, de forma muy antigua, y muy corto; un frac de color de café claro con cuello de terciopelo verde; una corbata blanca, tan alta que le llegaba a las orejas, con un lazo que casi le cubría la camisa: por íntimo, llevaba trabillas en los pantalones, una cadena monstruosa al cuello, un sombrero enorme en una mano, y en la otra guantes de algodón verde simétricamente empuñados. 
Hoy, desconocedores de la moda imperante en 1845, no podemos saber que elementos del atuendo de Justo Paniagua eran los que parecerían más ridículos a los ojos de todos los asistentes esa noche al Teatro del Circo que rompen a reír en masa ante la aparición del personaje en el palco. Pero la detallada descripción de su atuendo que hace Navarrete, nos indica que los lectores del Siglo Pintoresco, revista en la que apareció la novela por primera vez, eran conocedores de todas las imperiosas leyes de la moda que no había tenido en cuenta el provinciano Don Justo y por ello podían compartir la hilaridad del público del teatro ${ }^{14}$.

Navarrete, a pesar de una superficial crítica a las murmuraciones de la vida de esas clases elegantes, nos presenta un retrato de la sociedad urbana del Madrid de 1845 decididamente gozoso; no es extraño que cuando siete años antes escribía la necrológica de Larra, defendiera a la sociedad que Fígaro tanto había criticado. El entusiasmo por el ambiente, por las fiestas, por los personajes aristocráticos es palpable ${ }^{15}$. El novelista entra en una especia de exaltación, cuando describe el palacio de los Condes de $\mathrm{A}^{* * *}$ donde se desarrolla la fiesta:

La imaginación no podía concebir nada mas nuevo, más poético, ni más original, que la perspectiva que presentaba el salón a cuantos entraban en él; el perfume de las flores, el murmullo de las fuentes, las armonías misteriosas que parecían brotar de cada flor, de cada arbusto, la dulce claridad que comunicaba a todo un tinte pálido e indefinible, producían un éxtasis delicioso, en el cual la organización menos apasionada y mas fría, se remontaba a los espacios imaginarios. Por efecto de esta sensación inexplicable, como si ninguno se atreviese a turbar el silencio que allí reinaba, juzgando que en aquel sitio solo debían tener voz las fuentes que murmuraban, los pájaros que gorjeaban, los arbustos que se mecían agitados por un céfiro suave, no se oía el rumor de animadas conversaciones: todos hablaban bajo, y algunos

14. Es más, la vestimenta de Paniagua es un leit-motiv del relato. Se la describe en tres ocasiones: al principio del relato, cuando su atuendo es el de un aldeano rústico; en la aparición en el palco del teatro del Circo (la que he citado arriba) y finalmente en el baile del Palacio de los Condes de $\mathrm{A}^{* * *}$ ya vestido a la moda, pero llevando su atuendo sin la menor elegancia: "carecía de originalidad en su traje, y de soltura en sus maneras: no se atrevía a moverse por miedo de que se le bajase el cuello de la camisa; no osaba doblar las piernas por temor de que saltase un rico pantalón de satín negro; en fin, no levantaba los brazos recelando descomponerse el peinado». La insistencia en el aspecto cómico del vestuario de Paniagua indica hasta que punto la moda de le época era elemento fundamental en el relato.

15. El narrador, en este sentido, no pierde ocasión de comentar en relación con el malvado de la historia, el Conde de Peñaflor, que su título lo debía «menos a sus pergaminos, que a los tesoros de su opulento padre». De un falso conde, de un conde advenedizo, es más lógico esperar el comportamiento inmoral del que hace gala Peñaflor. 
más impresionables y más nerviosos, se limitaban a estrechar furtivamente

la mano de algún ser querido, deseando hacerle partícipe de sus emociones.

Esta alabanza sin reservas a la sociedad y la sociedad madrileña es la que hace que el novelista se preocupe en certificar la verdad de lo que cuenta y presente escenarios reales en los que sitúa su historia.

Uno de los elementos que más llaman la atención de esta novela, de fecha tan temprana en el desarrollo de este género en el siglo XIX, es su decidida apuesta por el realismo. Más aún: por la intención de ofrecer al lector una definida impresión de realidad, para ofrecer una muy clara incardinación de la fábula en ambientes reales, existentes, ciertos y conocidos de los lectores que se enfrentaban a la novelita en 1845. No nos encontramos aquí con Orbajosas, Vetustas o cualesquiera otras ciudades literarias, remedos de otras reales. Navarrete nos deja muy claro que la obra ocurre en Madrid, localiza con precisión sus escenarios e incluso nos indica con raro detalle la fecha de inicio de la acción: octubre de $1843^{16}$.

El café de Venecia, lugar en el que empieza y termina la historia es ya, por así decirlo, un viejo conocido en la historia literaria del XIX, ya desde la época en que un grupo de parroquianos se trasladaron desde esa café al del Príncipe, para fundar la famosa tertulia del Parnasillo. Mesonero Romanos lo menciona ${ }^{17}$, así como Galdós en varias de sus obras ${ }^{18}$. La animada y elogiosa descripción que hace Navarrete del café y de su público y ambiente fue recordada por Ramón Gómez de la Serna, otro enamorado de los cafés, en «La sagrada cripta de Pombo». El teatro del Circo, segundo escenario que aparece en la novela, era el teatro preferido de la alta sociedad madrileña, como nos indican Challamel ${ }^{19}$ y Madoz $^{20}$. Era lógico, por tanto, que allí acudieran los

16. Tanta precisión en los detalles pueden ser indicio que nos encontramos con una narración «en clave»; pero no he podido encontrar ningún dato que avale esta sospecha.

17. «Los cómicos en Cuaresma»

18. Los apostólicos, La Primera república y Cánovas.

19. «Ce thêátre est tres frécuenté par la bonne societé de la capital» (Challamel; 1845: 172)

20. «Hace pocos años que con el objeto de servir a las compañías gimnásticas que bajo la dirección de Abrillon, Paul y otros transpirenaicos vienen anualmente á ofrecer su habilidad a los madrileños, fue construido este teatro en la plaza del Rey, al fin de la calle de las Infantas, y en su construcción, aprobada para el objeto, se estuvo sin duda lejos de pensar, que algún día había de convertirse en teatro de ópera italiana, de baile serio, y hasta de verso. Pero la escasez de teatros de Madrid, y la progresiva afición del público, hizo habilitar este para dichos objetos, construyendo un escenario en uno de sus frentes, y procurando aproximar en lo posible lo demás a este nuevo servicio: mas como deja conocerse, no ha podido ser esta variación tan radical, que no se resienta aun en todas sus partes del primitivo origen de su institución, pues ni su figura, ni sus dimensiones están conformes con las reglas ópticas y acústicas que exige un teatro, y en el ornato carece también de la suntuosidad y elegancia que requiere la escena de 
protagonistas de la historia, a admirar el baile de Marie Guy-Stephan. Así nos lo dice el texto: «Era aquella noche una de las primeras representaciones de Gisela; y hallábase el coliseo ocupado por lo más escogido de la sociedad madrileña. Mme. Guy-Stephan bailaba su gracioso wals, siendo aplaudida con delirio». Gisela fue estrenada el 24 de Octubre de 1843, en el Teatro del Circo, y la bailarina protagonista, Marie Guy-Stephan, se convirtió en la gran estrella de la danza en Madrid por varios años. Como Navarrete ya nos había indicado que la obra comienza un día de octubre de 1843, las circunstancias temporales que en el texto se indican coinciden plenamente con la realidad

En cuanto al palacio de los Condes de $\mathrm{A}^{* * *}$, donde se celebraba el baile en el que se produce el desafío entre Peñaflor y Vivarramabla, la amplia experiencia de Navarrete como cronista de esos festejos hace pensar que su entusiástica descripción responde a un conocimiento directo de esa fiesta, una de las muchas fiestas a las que acudía en su papel de propagandista de la aristocracia.

Por lo que toca al duelo, hay suficientes noticias de que era una realidad social existente en la época y el propio Navarrete se debió ver mezclado en alguno, como prueba este críptico suelto, publicado en El Clamor Público el 23 de enero del mismo año de 1845 en que apareció por primera vez la novela: «habiéndose acercado Don Ramón de Navarrete a pedir explicaciones al Sr Don Juan Pérez Calvo, con motivo de un artículo inserto en la Revista de Teatros, han mediado entre ellos las que cumplen a personas de honor y delicadeza, quedando ambos mutuamente satisfechos»

\section{NOVELA DRAMATIZADA}

Misterios del Corazón es una perfecta representante de esa modalidad narrativa romántica que es el cuento dramatizado: un relato dividido en escenas con fuerte carga dramática, en gran parte dialogadas, con partes que se dejan a la imaginación del lector para centrarse el autor en los puntos culminantes, con personajes claramente diferenciados y enfrentamientos muy definidos ${ }^{21}$. A lo

una capital notándose que las entradas se hallan á los costados del escenario lo que sería causa de un conflicto para la concurrencia si por desgracia ocurriese un fuego. A pesar de todo desde que el Señor Salamanca tomó a su cargo la empresa de este teatro, se vieron en el decorado de la escena y en el adorno del edificio mejoras notables; y al celo de este empresario, que procuró contratar lo más notable de Europa en cl género de canto, como son la Persiani, Ronconi, Salvi y otros muchos célebres cantantes, se debió quizás la preferencia que lo más escogido y brillante de la sociedad madrileña dio a este, sobre todos los demás teatros, en términos, que empezó a competir con ventaja con los del Príncipe y la Cruz.» (Madoz

21. Para una mejor explicación del cuento dramatizado romántico véase Rodríguez Gutiérrez, 2004, 214-232.

Anales, 24, 2012, pp. 43-66 
que se añade que la amplia experiencia teatral de Navarrete en el momento en que acomete esta novela, le lleva a concebir y desarrollar la acción en términos teatrales. Es sencillo ver que la acción se desarrolla en cinco momentos, cinco actos, con los siguientes escenarios: Café de Venecia, Teatro del Circo, Gabinete en el Palacio de la Marquesa de Vivarrambla, Palacio de la Condesa de $A^{* * *}$ y de nuevo el Gabinete de la Marquesa. La acción se desarrolla en su casi totalidad a través del diálogo. Incluso el principio y el final de la novela nos son transmitidos por un recurso claramente teatral: un grupo de personajes que conversan y hablan de los protagonistas: de esta manera sabemos los antecedentes de la historia que vamos a «ver» en la novela, y de la misma manera sabemos el desenlace. Navarrete utiliza, incluso, el viejo recurso de la «relación» teatral para no presentar directamente el duelo final entre Vivarrambla y Peñaflor ante los ojos del lector (aunque sí aparece un dibujo de ese duelo; el único de los grabados que acompañan a la historia -como veremos después- que no sigue estrictamente el desarrollo de la narración).

Utiliza también Navarrete el efecto de la «bajada de telón», tan frecuente en el cuento dramatizado para subrayar momentos culminantes y dramáticos, al estilo del final de un acto teatral; es el caso de ese desmayo de Clementina, tras expulsar primero de su casa al marido adúltero y al taimado Peñaflor. Una vez sola, cae desmayada y así termina el capítulo y la entrega: «Cuando Clementina se vio sola, faltole la energía que basta entonces la había sostenido; turbose su vista, sintió un dolor agudo en el corazón y exhalando un grito convulsivo, cayó desplomada sobre la magnífica alfombra que cubría el pavimento.» Dramático final, que perfectamente podemos imaginar en un final de acto, con el telón descendiendo hasta ocultar el cuerpo examine de la bella marquesa entre los aplausos del público. Efecto que acentúa Castelló con su ilustración, con esa atracción erótica pervertida que siente el romanticismo por las mujeres sufrientes, inconscientes, agonizantes o muertas ${ }^{22}$.

Un elemento más de la teatralización de la narración es la actitud del narrador, que es ante todo visual. Sin llegar a ser una cámara que registra, lo más importante para él es la descripción de ambientes, fisonomías y vestuarios. Apenas hay inmersiones en la mente de los personajes; en vez de explicar los antecedentes el narrador, Navarrete prefiere que los personajes hablen ante el lector y así cuenten no sólo la historia sino los elementos anteriores a ellas, indispensables para la comprensión de los hechos. Esa es la función que cumplen Solís «abogado novel, [...] mozo de buen aspecto y de no peor talante, que tenía sus puntas de satírico y epigramático, aunque Dios no le hubiera dotado del

22. Vease Rodríguez Gutiérrez, 2009.

Anales, 24, 2012, pp. 43-66 
gracejo suficiente para hacer reír siempre que hablaba», Enrique «estudiante de humanidades, que en vez de ser en los libros, las estudiaba en la especie humana» y Alberto «artista notable no menos por el mérito de sus obras, que por la espesa barba que casi le cubría el rostro y la prematura calva que comentaba en la frente, y se perdía en el principio de la nuca». Son estos tres personajes los que con sus conversaciones nos van a informar de la historia de los personajes que vamos a conocer, al principio del relato, en el café de Venecia.

La experiencia teatral previa de Navarrete y la influencia del costumbrismo reinante en la época (el mismo Navarrete colabora en Los españoles pintados por sí mismos, 1843-1844, con dos tipos «La coqueta» y «El elegante») dan forma a este narrador que es ante todo observador y descriptor. El autor dramático que es Navarrete acude con preferencia al diálogo para narrar la historia, el costumbrista introduce en la novela un narrador que es en sustancia idéntico a la voz que nos habla en los artículos de costumbres: observador de la realidad, preocupado por la pintura de escenarios y fisonomías, ausente de la mente de los personajes; muy lejos todavía del narrador omnisciente de la novela del realismo.

Navarrete también fue entre otras cosas, cultivador del costumbrismo. Ya hemos mencionado sus dos colaboraciones en Los españoles pintados por sí mismos. En Madrid por dentro y por fuera $(1873)^{23}$, colabora con dos artículos «Un gran baile» $\mathrm{y}$ «Un asalto», prueba, una vez más, de su conocimiento de las costumbres sociales de la burguesía y aristocracia. Llama la atención a este respecto, que el protagonista de una de sus colaboraciones en Los españoles..., «el elegante», pase, con armas y bagajes, a convertirse en la novela en el Conde de Peñaflor:

El uno era un elegante, un dandy, o un león en toda la extensión de la palabra; vestía con extremado lujo y a la vez con arreglo al último figurín llegado de Francia; tenía los cabellos peinados hacia atrás y graciosamente rizados; un escaso bigote sombreaba apenas su pequeña boca, y unas patillas no menos escasas y estrechas, servían también de adorno a su pálido semblante. Hasta su actitud negligente y estudiada a un tiempo, contribuía a caracterizarle mejor: habíase colocado bastante lejos de la mesa que servía de centro al círculo, y sin apoyo de ninguna especie, con una mano sostenía un platillo de china que se ostentaba una graciosa pirámide, y con la otra llevaba a los labios de tarde en tarde, pequeñas cucharadas de aquel helado. Un magnífico paletot, caído sobre la silla que ocupaba, permitía ver la riqueza y el buen gusto de su traje.

No sólo lo apariencia física, sino también la actitud y la conducta de Peñaflor, coinciden a la perfección con el retrato del «Elegante». Palabras como «dandy»

23. Pueden consultarse estos artículos en la edición de esta obra que ha publicado María Ángeles Ayala (2008)

Anales, 24, 2012, pp. 43-66 
o «león» aparecen en ambos textos: «el antiguo pirraca, el moderno lechuguino, puede escoger entre una porción de títulos, a cual más pintoresco y castizo, como dandy, fashionable, león, o por mejor decir, lion, si hemos de hablar técnicamente» [todas las cursivas son de Navarrete] (Los españoles..., 1843-1844: 45). Se opera aquí ese trasvase de tipos a personajes de la que habla Gutiérrez Sebastián a propósito de Pereda: «la filiación costumbrista de gran parte de los caracteres literarios de las novelas estudiadas que proceden en muchos caso de tipos aparecidos ya en los primeros artículos de costumbres de este narrador» (2002: 345). Esto es, cabalmente, lo que ocurre en Misterios del Corazón; los dos tipos que Navarrete había incluido en las españoles, «La coqueta» y «El elegante» se transforman, apenas un par de años después en Adela de Arambarri y el Conde de Peñaflor. El novelista, echa manos de los tipos creados por el costumbrista, movido por un deseo muy semejante, si no idéntico, al que indica Ayguals e Izco en su «Dedicatoria» inicial de María o la hija de un jornalero.

Yo creo que pudieran muy bien escribirse verdaderas y acabadas historias, que destellasen por do quera todo el interés, toda la amenidad, todos los alicientes de la novela, con solo eslabonar hábilmente la fantasía con la realidad, siempre instructiva y respetable, de manera que la parte de la invención no perjudicase la veracidad de los sucesos (Cito por Sebold, 2007: 23)

\section{NOVELA ILUSTRADA}

En la edición del Siglo Pintoresco (1845) la novela va acompañada por 12 dibujos, obra de Vicente Castelló, que se integran muy acertada y adecuadamente en el transcurso de la lectura. Esta es una de las narraciones que merece más ilustraciones de la revista (Un cuento de hadas, también de Navarrete, publicada unos meses después, tan solo tiene tres grabados) y además va ornamentada con trabajadas letras capitulares. Los dibujos de Castelló representan una segunda narración paralela, subrayando los momentos más espectaculares y dramáticos de cada parte, de manera que la sucesión de imágenes pudiera servir como un pequeño resumen de la historia. Castelló presenta el principio y final de la novela a través de la tertulia con la que se abre y cierra la narración. Ente ambas tertulias, el dibujante va reflejando una serie de elementos significativos: la salida del café de Venecia rumbo al teatro del Circo, la escena en que una ofendida e indignada Clementina abandona el palco del teatro, acompañada de Peñaflor, ante la indiferencia del Marqués y de su amante, Justo Paniagua dormido en la ópera, la separación del matrimonio tras la prueba del adulterio del Marqués, el cuerpo inconsciente de Clementina, la fiesta en el Palacio de los Condes de $\mathrm{A}^{* * *}$, Clementina deslumbrante en esa fiesta, la discusión que acaba en desafío, el Marqués, escondido en el 
gabinete de Clementina, comprobando que el Conde nunca ha sido amante de su esposa, y el duelo entre los dos rivales.

Hay que tener en cuenta que Castelló ${ }^{24}$ era también el director de la revista y esta abundancia de dibujos significativos, así como de ornamentos con los que la novela apareció el El Siglo Pintoresco, revela el interés por subrayar la importancia que se concedía desde la revista, a la novela de Navarrete. Cada capítulo va iniciado por una ornamental letra capitular, elemento excepcional en la revista, y los dibujos con que se ilustran son de gran tamaño y fina ejecución.

Esta sucesión de imágenes posee también las características que antes hemos visto en la novela. En efecto a través de las imágenes nos asomamos también a los escenarios en que ocurre la obra: tres de los grabados nos presentan el Café de Venecia, dos el Teatro del Circo, tres la fiesta y el baile en el palacio de los Condes de $\mathrm{A}^{* * *}$ y otros tres ocurren en el interior de la vivienda de la marquesa de Vivarrambla. Como ocurre en la narración textual, las imágenes nos presentan la vida y las actividades de la alta sociedad: dos imágenes de la tertulia del Café de Venecia, un elaborado grabado del Teatro del Circo, por medio de una escena con tres planos en la que vemos en el primero a Clementina abandonando el palco acompañada de Peñaflor, en un segundo plano al indiferente Marqués de Vivarrambla contemplando el escenario del teatro junto a su amante, y al fondo, en el palco contiguo un espectador en pie, aplaudiendo a la Guy-Stepham que, se supone, acaba de culminar uno de sus números. Especialmente significativa es la escena de la fiesta en el palacio de los Condes de $\mathrm{A}^{* * *}$. Castelló se esfuerza por reflejar el lujo, la decoración y la nutrida concurrencia al palacio. En la imagen está presente la florida decoración, los bustos de escritores y artistas, los carteles que Navarrete menciona y no menos de treinta y cuatro invitados, distribuidos en varios planos, conversando en grupos en relajada actitud, en lo que se quiere presentar como una escena en la que podemos contemplar a la alta sociedad madrileña de la época, divirtiéndose.

Otra característica que podemos advertir es hasta qué punto el dibujante se preocupa también por las vestimentas de los personajes, sobre todo de los masculinos. Es el caso por ejemplo de la tertulia que cierra el relato en la que la entallada levita de Solís, que habla de pie ante la mesa se diferencia perfectamente de la capa con que se cubre uno de los contertulios. O de la escena en la que se produce, ante la mirada de Clementina, el desafío entre Peñaflor y Vivarrambla, dominada por la cuidad vestimenta de los dos rivales.

24. Para más información sobre Castelló, véase Rubio Cremades, 2008: 385.

Anales, 24, 2012, pp. 43-66 
El lujo que Navarrete describe con tanto detalle es objeto también del lápiz de Castelló. Lo podemos ver en la imagen de Clementina desmayada en su gabinete. Navarrete nos había indicado ya en el texto que la estancia estaba adornada con «un reloj de porcelana de Sevres» y que la alfombra, era «magnífica», así como que el gabinete era «elegante». Castelló completa esa definición con una acumulación de detalles en su dibujo, que refuerzan la imagen del lujo que rodea a la inconsciente figura de Clementina. Está desde luego el reloj, pero también una mesa-velador, de un solo y ornamentado pie, con revistas y periódicos sobre ella, un sofá y un sillón ante una chimenea, rodeada ésta con un salva fuegos de rejería, y sobre cuya repisa hay un ornamentado candelabro. Los cuadros en las paredes, el papel de las mismas, la alfombra que cubre por completo el suelo de la habitación. El dibujante hace un consciente esfuerzo de representar ese lujo y esa elegancia, con la fuerza que tiene la imagen para llegar al lector de la revista y reforzar así las impresiones del texto.

Tan sólo hay una imagen que no sigue estrictamente la narración de Navarrete y es la escena del duelo, que sólo conocemos por el resumen final de Solís y que nos representada gráficamente por un muy atinado dibuje en el que los contendientes siempre perfectamente vestidos, se apuntan mutuamente con la pistola. Pero gracias a esta licencia de Castelló, la sucesión de imágenes se constituye en una auténtica narración paralela, poniendo ante los ojos del lector-espectador todo los momentos culminantes de la historia. Hay muy pocas ocasiones en las que narrador y dibujante estén tan compenetrados y en los que una serie de imágenes refuerce de manera tan perfecta y apropiada la historia.

\section{CONCLUSIÓN}

Misterios del corazón ofrece una serie de puntos de interés que deben tenerse en cuenta a la hora de valorar la aparición de la novela realista en España. Propone una narración centrada en ambientes urbanos y elegantes, con un inequívoco tono laudatorio hacia los personajes de la aristocracia y de la alta sociedad que en ese escenario se mueven, sin un atisbo de la crítica que, más moderada, más acerba, es tan habitual encontrar en los escritos que parten del molde del costumbrismo. Si Navarrete no siguió por ese camino es porque descubrió que esa misma temática podía reflejarse mucho mejor y con más éxito en las crónicas sociales en las que se hizo especialista. Pero su intento da fe de que en la década de 1840 el interés por la observación de la realidad ya está presente en libros, periódicos y revistas, y que esa observación abre nuevos escenarios narrativos que ni la novela histórica, ni el costumbrismo, casi siempre centrado en la clase media, habían tenido en cuenta. 


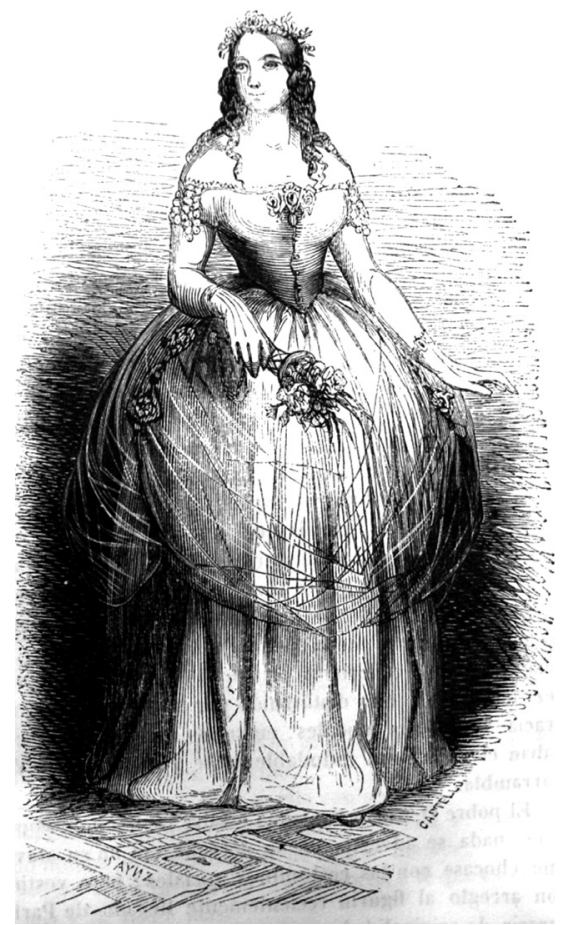

Clementina en la fiesta

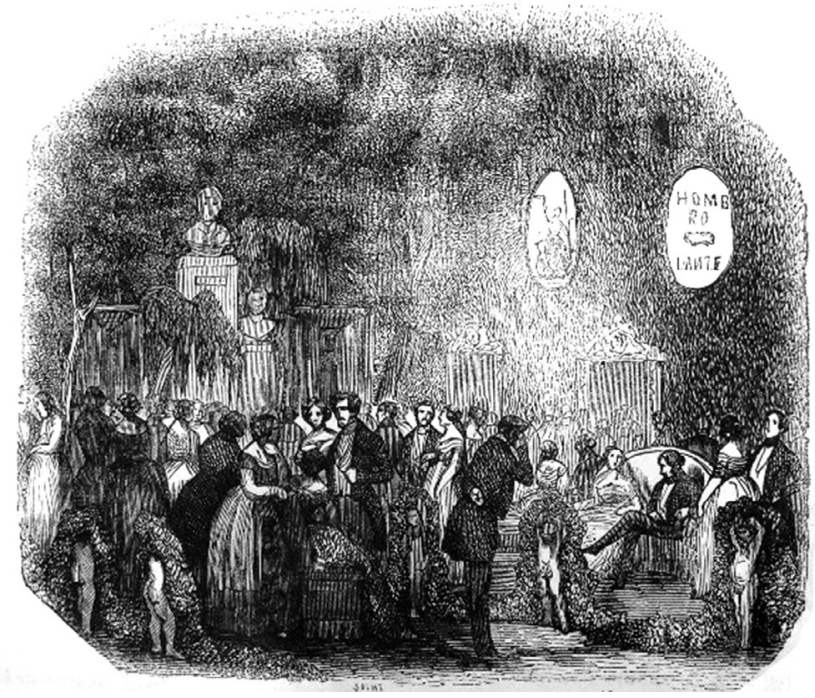

El baile

Anales, 24, 2012, pp. 43-66 


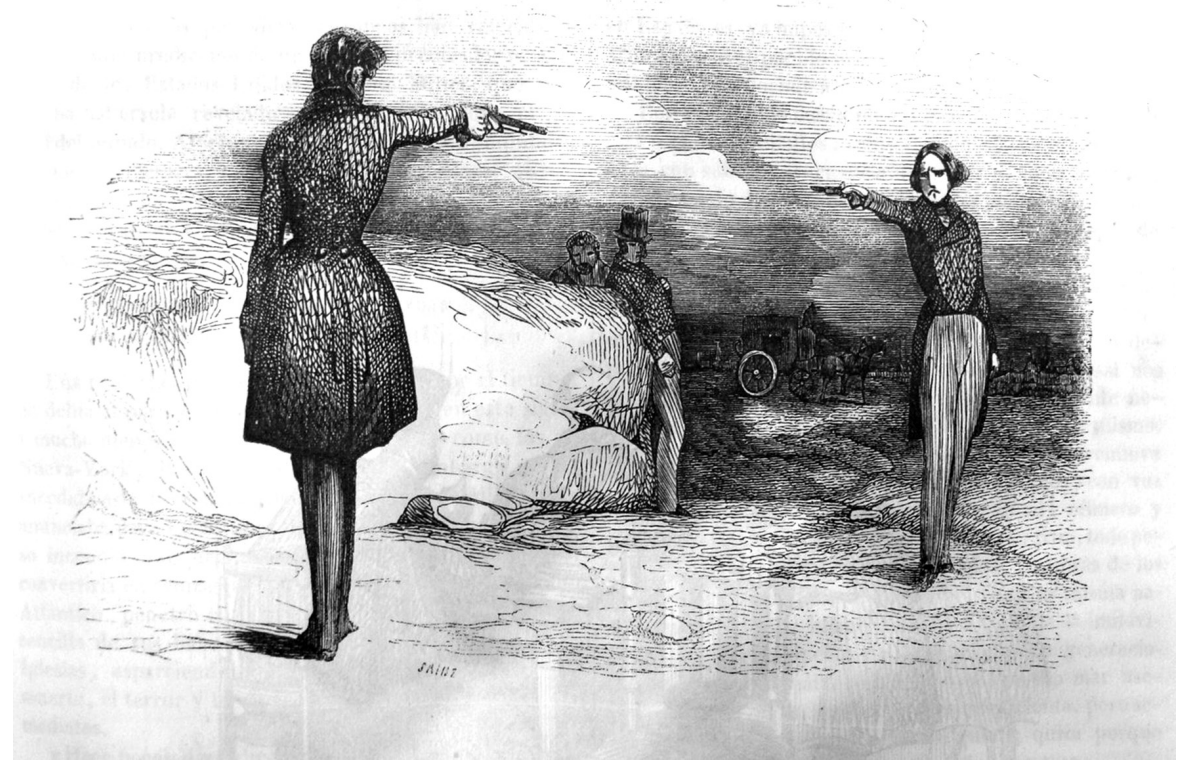

El duelo

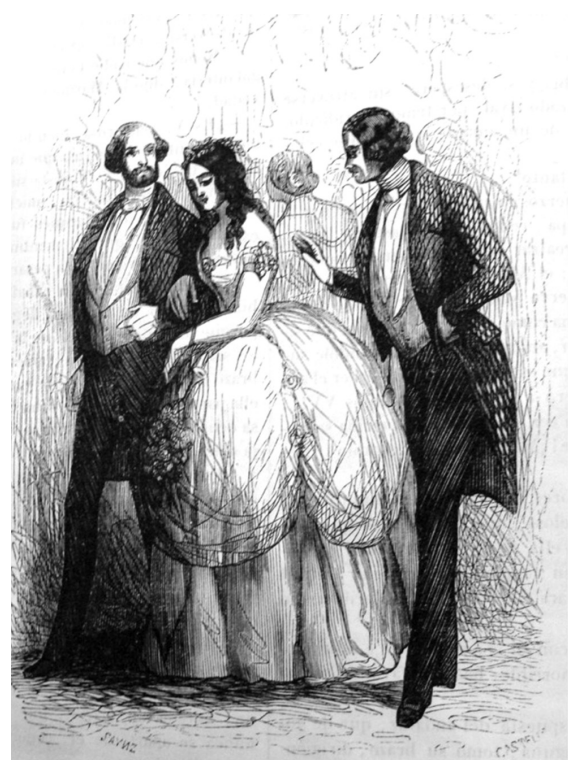

Desafío

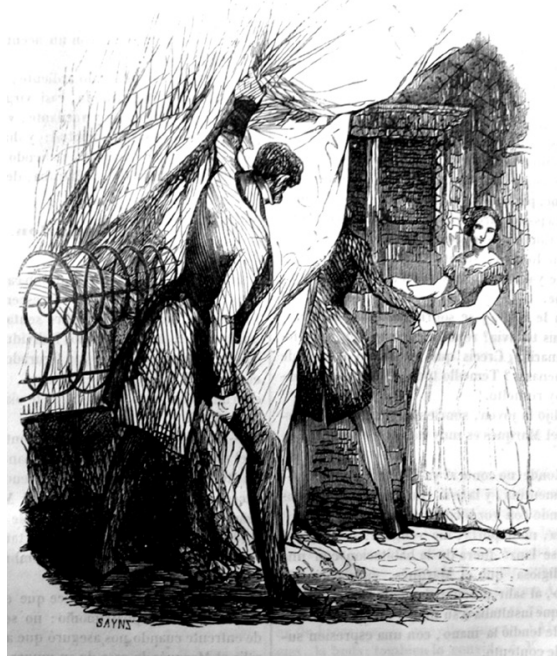

En la alcoba

Anales, 24, 2012, pp. 43-66 


\section{BIBLIOGRAFÍA}

Alarcón, Pedro Antonio de. Diario de un testigo de la Guerra de África. Madrid. Gaspar y Roig. 1860.

Azorín. «Las apariencias» ABC. 20 de julio de 1946. 3

Challamel, Augustin. Un été en Espagne. Paris / Madrid. Challamel editor / Casimir Monier. 1843

MARTíNEZ DE VELASCO, E. «Don Ramón de Navarrete» La ilustración española y americana. Año XXV. 1891. 165-166.

MenÉndez Pelayo, E. Memorias de uno a quien no sucedió nada. Introducción y edición de Benito Madariaga de la Campa. Santander. Estudio. 1983.

NAVARRETE, Ramón de. «Necrología. Larra» Gazeta de Madrid. No 820.4 de marzo de 1837. 4.

Ovilo y Otero, Manuel. «Don Ramón de Navarrete. Administrador de la Imprenta Nacional y Director de la Gaceta de Madrid» Escenas contemporáneas. Revista biográfica y necrológica, científica, literaria y artística. 1. 1860. 49-54.

Rodríguez GuTiÉRrez, Borja. Historia del cuento español. 1764-1850. Madrid / Frankfurt. Iberaomericana / Vervuert. 2004

RODRÍGUEZ GUTIÉRREZ, Borja. «Corrupción, pecado y perversión. La cara oscura de la fantasía romántica» Artifara. 9. 2009. http://www.artifara.unito.it/Nuova\%20serie/N-mero-9/Addenda/default.aspx?Login=true\&oid=216\&oalias=

RUBio CREMADES, E. «Las ilustraciones en el Panorama Matritense y en las Escenas Matritenses de Mesonero Romanos, hechas en vida del autor» La literatura española del siglo XIX y las artes. Edición de J.-F. Botrel, Marisa Sotelo, Enrique Rubio, Laureano Bonet, Pau Miret, Virginia Trueba, Noemí Carrasco. Barcelona. PPU. 2008. 375-388.

Rubio Cremades, E. «El Crimen de Villaviciosa, de ramón de Navarrete: entre la crónica de sociedad y el relato de misterio» Anales de Literatura Española. (Serie monográfica $n^{\circ}$ 10. Escritores olvidados, raros y marginados). $\mathrm{N}^{\circ} 20.2008$. 285-302.

SEBOLD, R. P. En el principio del movimiento realista. Credo y novelística de Ayguals de Izco. Madrid. Cátedra. 2007.

\section{APÉNDICE}

\section{Larra}

¡Murió Fígaro!!! El escritor cuyas obras por lo general excitaban la risa y eran para todos un objeto de predilección y de aprecio, terminó su vida cometiendo un crimen, destruyendo su propia existencia. Hemos perdido una de las más bellas flores de nuestra corona literaria; su muerte deja un vacío difícil de 
llenar, pero su memoria vivirá siempre consignada en sus bellos escritos. Su existencia ha sido cual una rosa cortada antes de abrir; muy joven todavía, no se le apreciaba menos por lo que prometía ser en adelante que por lo que era actualmente. No indicaremos nosotros los motivos que le impulsaron a tan violenta resolución: muévenos a ello la delicadeza y un sentimiento de compasión hacia aquél, que adornado de un talento brillante, no tuvo el suficiente para sobreponerse a las pasiones y pereció víctima de ellas.

Todos los periódicos de esta capital han hablado ya largamente de un suceso que con razón ha llamado la atención pública, y cada uno de ellos le ha juzgado según su opinión o sus afecciones. Nosotros hemos querido aguardar a que se moderase algo el justo sentimiento que todos hemos tenido, para hablar con mayor imparcialidad y menos acaloramiento, para no exponernos a soltar expresiones que después tuviéramos que rectificar. Ningún vínculo, ninguna relación nos unía al malogrado Larra, ni abrigábamos animadversión alguna hacia él. Admirábamos el talento, aunque a veces no estuviésemos conformes con sus opiniones, y hemos sentido como el que más una pérdida que lamentarán largo tiempo la literatura y la humanidad. Hecha esta sincera protesta, creemos quedar a cubierto de cualquier ataque infundado, o de alguna torcida interpretación.

El que lea los escritos festivos y satíricos, a la par que filosóficos, del desgraciado Fígaro y los compare con su fin trágico, hallará una manifiesta contradicción, un sensible diferencia entre lo escrito y lo puesto en práctica. El escritor que se mofaba de las preocupaciones de los demás, el que satirizaba las costumbres y con el arma del ridículo combatía los vicios y los defectos, no estaba exento ni de aquellos ni de estos. Ostentaba una filosofía nada común y un entendimiento claro y despejado: o era aquella aparente y falsa o éste se vio ofuscado cuando se lanzó al crimen. Así es la vida humana. Su exterioridad resplandeciendo con acciones generosas y sentimientos elevados... es un sepulcro cubierto con una losa magnífica, que oculta dentro podredumbre y hediondez.

Ideas exageradas o una fantasía acalorada llevaron a Larra al sepulcro, que abrió con sus propias manos sin acordarse de que su vida ya no era suya, que debía consagrarla a su patria y a sus hijas, que su ejemplo seria tal vez pernicioso a esa sociedad no tan estúpida ni tan corrompida como se pretende, y en la cual aún brillan virtudes y sentimientos nobles a la par de acciones desinteresadas. ¡Y así era como pretendía corregir los vicios?... ¿así como quiso demostrar la exactitud de sus doctrinas?... Por fortuna esa sociedad, que se calumnia, que se llama estúpida y corrompida, no está tan desprovista de ilustración y de virtud que no se aparte de un ejemplo vivo de demencia, ni 
deje de reprobar altamente un acto que si mueve a compasión, causa también horror y estremece a la naturaleza.

¡Qué buscaba Larra en el mundo que no hallaba?... ¿No era padre, no era esposo?... ¿No tenía qué cumplir con estas sagradas obligaciones?... ¿No encontró un amigo a quien amar?... ¿No le ofrecía la amistad sus más puros goces, los únicos verdaderos tal vez, cuando son desinteresados?... Si tenía virtudes, ¿no encontró un corazón que las comprendiese?... ¿No obtuvo todo el galardón dispensado al talento?... Porque no hay satisfacción mayor ni recompensa más grande que hallarse admirado y aplaudido de un pueblo entero, y ver sobres su cabeza ciñendo sus sienes una corona de gloria eterna, inmarcesible, la corona del talento. Y aquella admiración hubiera crecido y aumentadose de día en día y hubiera llegado uno en que su nombres tal vez se citaría entre los de nuestros sabios más ilustres y más virtuosos.

Pero su muerte ha echado un borrón a su gloria; su sangre, vertida por él mismo, ha caído sobres sus obras y las ha deslustrado. Ha sido cual la mancha en la honra de una mujer, que nada es capaza de bórrala. Quien leyese estos tres tomos de Fígaro, salpicados todos de gracias y de chistes, abundando en cada página la sal ática y el gracejo, ¿podría imaginar nunca que llegaría una ocasión en que aquel que tanto hizo reír acabase con un fin trágico?... ¿Pudo nadie pensar que un día, sobre una tumba, y una tumba ensangrentada, sirvan aquellos tres tomos como un recuerdo amargo, temible, como un contraste de la vida con la muerte del que lo escribió?... ¿Pudo ocurrirle a nadie jamás que el mismo pueblo a quien tanto hizo reír, lloraría a poco detrás de su féretro, todo entero?... Pero el pueblo no lloraba al hombre, lloraba al poeta. No sabía si aquel era digno de su sentimiento, pero sí que éste era digno de su dolor y su admiración.

Quizás la catástrofe que lamentamos ha sido producida por ideas falsas, por esas ideas modernas que desgraciadamente empiezan a cundir entre nosotros y que se reproducen y aumentan cada día más. Deber es de los escritores públicos combatirlas y demostrar los falsos cimientos en los que se apoyan. La juventud no reflexiona ni precave nada, seducida por brillantes e impracticables teorías, cae en el lazo que le tiende esas doctrinas corruptoras... ¿Y cuál es el castigo de su ceguedad, cuál el término de su fascinamiento?... ¡El suicidio! ¡La muerte!

¡Lloremos todos la pérdida de Fígaro; lamentemos su destino que le compelió a cometer un crimen!... ¡Pero cuenta con imitarle como a Larra!... Cuenta con elogiar un acto de desesperación que la humanidad y la moral pública unánimemente reprueban. ¡Pereció el autor de Macías!... Vertamos una lágrima en su memoria y coloquemos una corona de laurel sobre la fría losa de su 
sepulcro... Suicidóse Larra... No nos acordemos de esto sino como de una lección terrible, como de una acción vituperable. Separando el hombre del literato, reprobémosle como lo primero pero ensalcémosle como poeta distinguido e ilustrado. Murió Larra; pero Fígaro vive y vivirá eternamente.

Fecha de recepción: 12-1-2012

Fecha de aceptación: 30-5-2012 